\title{
HYDROTHERMAL TREATMENTS TO PROMOTE SURFACE INACTIVATION AND INCREASED FLEXIBILITY IN THREE HARDWOODS
}

\author{
Matheus Lemos de Peres ${ }^{1}$, Rafael de Avila Delucis ${ }^{1, \diamond}$, Rafael Beltrame ${ }^{1}$, Darci Alberto Gatto ${ }^{I}$
}

\begin{abstract}
In the present study, three juvenile hardwoods (namely sycamore, pecan and london plane) were treated by boiling, steaming and microwave. Trees from Platanus x acerifolia (sycamore), Carya illinoinensis (pecan) and Luehea divaricata (london plane) were selected in homogeneous forests located in southern Brazil. Each hydrothermal treatment was performed for $60 \mathrm{~min}$. In general, the hydrothermal treatments caused a certain surface inactivation effect, which was marked by decreased surface roughness, increased hydrophobic character and darkened colour patterns. Also, both decreased stiffness and strength, as well as increased deflectibility were obtained. These mechanisms were attributed to degradation in fine segments from amorphous polysaccharides, leaching of some organic extractives and fragmentation of lignin, as indirectly indicated by infrared spectra.
\end{abstract}

Keywords: Boiling, london plane, microwave, pecan, steaming, sycamore.

\section{INTRODUCTION}

There is a great scientific effort addressing to improve wood properties by physical and chemical treatments and, consequently, increasing its range of applications. These wood treatments can solve some wood disadvantages, such as low durability, low dimensional stability, heterogeneous colour pattern, and lack of certain mechanical characteristics. In general, a wood treatment is a deliberate attempt of induce controlled changes in certain chemical compounds.

For instance, there are certain treatments capable of promote closure of wood pores, forming a new layout cross-linked between the components of the cell wall, in which some molecules were joined to each other (Herrera et al. 2015). These closed sites become chemically unstable and the attractive forces inside them are reduced, which hinder intermolecular bonds formation with water, gases, extractives, adhesives, dirt particles and microscopic dust (Aydin and Demirkir 2010). These effects on wood surface are called as surface inactivation and may hinder wetting to occur, leading to negative effects in moisture uptake and adhesion performance (Gérardin et al. 2007). Thus, the larger the closure of wood pores, the higher the surface inactivation, the smaller the wood wettability and the smaller the wood bondability.

The surface inactivation may also lead to expulsion of oleic extractives on wood surface (Cademartori et al. 2013) and hinder the access of hydroxyl groups onto the wood cell wall (Piao et al. 2010). For Frybort et al. (2014), some wood extractives (namely fatty acids, terpenes, phenols, and so on) may migrate to outside wood, becoming a resinous layer, leading to increase in surface energy. The inactivated wood surface also presents smaller roughness, reducing losses in planning machine and yielding high quality wood surfaces, which may be important for many wood applications (Gündüz et al. 2008). 
From a macroscopic standpoint, these surface changes are visible at naked eye by wood colour. A homogeneous colour pattern is a desired characteristic for solid wood parts and, because of that, it is related to high value products. Some previous studies dealt with thermal and hydrothermal treatments, which aimed at improving the wood surface, especially its colorimetric properties. These modifications include: microwave radiation (Ozarska and Daian 2010), steaming (Peres et al. 2016) and boiling (Gatto et al. 2008).

Other current studies have been reporting important findings on surface inactivation, as well as mechanical properties, using thermal (Cademartori et al. 2013) or hydrothermal treatments (Hughes et al. 2015). These already developed wood products were designed for both indoor (e.g. interior furniture, picture frames, utensils, sporting goods and so on) and outdoor (e.g. decking, cladding and garden furniture) applications (Biziks et al. 2019). According to Hughes et al. (2015), a combination of effects induced by heat, pressure and steam can avoid some losses occurred in single step heat treatments, which indicate that hydrothermal treatments may be a better way to produce controlled chemical changes in wood if compared to single step modifications.

For instance, in their work, Peres et al. (2016) reported physical features of two waterlogged hardwoods (namely Cariniana legalis and Melia azedarach) subjected to microwave heating. According to these authors, the treatment yielded increases in both internal temperature and moisture content, leading to lignin plasticization, which may be of interest for some post-interventions, such as wood bending and conformation of curved wood parts. In the present study, three hardwoods (namely sycamore, pecan and london plane) were heated by steaming, boiling and microwave and characterized for surface inactivation performance and bending properties.

\section{MATERIALS AND METHODS}

\section{Raw material selection}

Trees from Platanus x acerifolia (sycamore), Carya illinoinensis (pecan) and Luehea divaricata (london plane) were selected in homogeneous forests located in southern Brazil, following ASTM D5536 (2017). Afterwards, 60 prismatic wood samples were cut from air-dried juvenile lumbers with the dimensions of 2,5 $\times 2,5$ $\times 10 \mathrm{~cm}^{3}$ (larger dimension oriented in the axial direction). The samples were then stored in a climatic chamber (at $65 \% \mathrm{RH}$ and $20^{\circ} \mathrm{C}$ ) until reach equilibrium moisture content. Detailed information about the raw material selection is available in Delucis et al. (2014a), although some key anatomical features were inserted in Table 1.

Table 1: Anatomical properties of the hardwood's fibres.

\begin{tabular}{|c|c|c|c|}
\hline Fibre size & Sycamore & Pecan & London plane \\
\hline $\mathrm{L}_{\mathrm{fib}}(\mu \mathrm{m})$ & $1647,39^{(17,99)}$ & $1131,69^{(17,08)}$ & $1506,89^{(19,17)}$ \\
\hline $\mathrm{D}_{\mathrm{fib}}(\mu \mathrm{m})$ & $23,79^{(17,66)}$ & $16,99^{(13,68)}$ & $20,22^{(14,92)}$ \\
\hline
\end{tabular}

\section{Hydrothermal treatments}

Wood samples were treated by boiling, steaming and microwave radiation. Temperatures were set based on that glass transition $\left(\mathrm{T}_{\mathrm{g}}\right)$ ascribed to the wood lignin in its natural state $\left(70^{\circ} \mathrm{C}\right.$ to $\left.105^{\circ} \mathrm{C}\right)$, determined by Placet et al. (2008). Boiling was carried out at atmospheric pressure by immersion in boiling water (about 100 $\left.{ }^{\circ} \mathrm{C}\right)$. Steaming was performed into a plastic tank with two holes: the first for water vapour inlet and the second for condensed water outlet. The heat source for steaming and boiling treatments came from an electrical resistance. For microwave radiation, waterlogged samples were subjected to microwaves at 2,45 GHz frequency and $900 \mathrm{~W}$ nominal potency. Each hydrothermal treatment was performed for $60 \mathrm{~min}$. 


\section{Characterization of the wood}

Qualitative chemical analyses were performed in wood powders using a Jasco FT-IR 4100 spectrometer based on 36 scans from $4000 \mathrm{~cm}^{-1}$ to $650 \mathrm{~cm}^{-1}$ range and resolution of $4 \mathrm{~cm}^{-1}$. The obtained spectra in diffuse absorbance was smoothed with five points and normalized to unity at $1030 \mathrm{~cm}^{-1}$ peak $(\mathrm{C}-\mathrm{O}$ stretching in cellulose). Wettability was evaluated on both radial and tangential planes of 3 prismatic samples of each group. A $8 \mu \mathrm{l}$ distilled water droplet was deposited and its contact angle was monitored for $120 \mathrm{~s}$. These measurements were performed using an Optical Tensiometer (Theta Lite TL101, Biolin Scientific Inc., Finland). Surface roughness was determined using a 899 Homis roughness meter based on two parameters, namely: roughness average (Ra) and average distance between peak and valley (Rz), as following the Japanese standard JIS B0601 (JIS 2001). Both radial and tangential planes of 15 samples of each group were evaluated and these data were presented without differentiating the planes because there were no significant differences between them. Colour changes were ascertained using a CR-400 spectrocolorimeter (Konica Minolta brand) configured with a D65 source light and angle of observation of $2^{\circ}$ on both radial and tangential planes of 15 samples of each group. Static bending was carried out in 15 prismatic samples from each group with the dimensions of $1,0 \times 1,0$ $\times 20,0 \mathrm{~cm}^{3}$ using a EMIC universal testing machine, following ASTM D143 (2014). Load vs. deflection curves were analysed to calculate brittleness, as proposed for Peres et al. (2016). All data were statistically analysed, using multifactorial ANOVA tests at significance levels of 0,05 followed by means tests by Tukey method.

\section{RESULTS AND DISCUSSION}

\section{Infrared spectroscopy}

Figure 1 shows qualitative results about the main chemical groups for the pristine and treated hardwoods. All samples showed similarly shaped spectra, which indicates similar chemical compositions. Compared to the pristine woods, the treated ones showed slight attenuations in the peaks at $3300 \mathrm{~cm}^{-1}, 1027 \mathrm{~cm}^{-1}, 1508 \mathrm{~cm}^{-1}$ and $1690 \mathrm{~cm}^{-1}$. The peak at $3300 \mathrm{~cm}^{-1}$ is related to $\mathrm{O}-\mathrm{H}$ stretching and may be attributed to remaining moisture. Probably, the warm and humid environment caused by the hydrothermal treatments caused degradation in fine segments from amorphous polysaccharides and, consequently, decreasing of the number of hydroxyl bonds between wood and water (Pandey 1999). The slight attenuation of the peak at $2700 \mathrm{~cm}^{-1}$ is related C-H stretching in methyl or methylene groups from fatty acid methyl esters or phenolic acid methyl esters, indicating that there was leaching of some organic extractives due to water action.
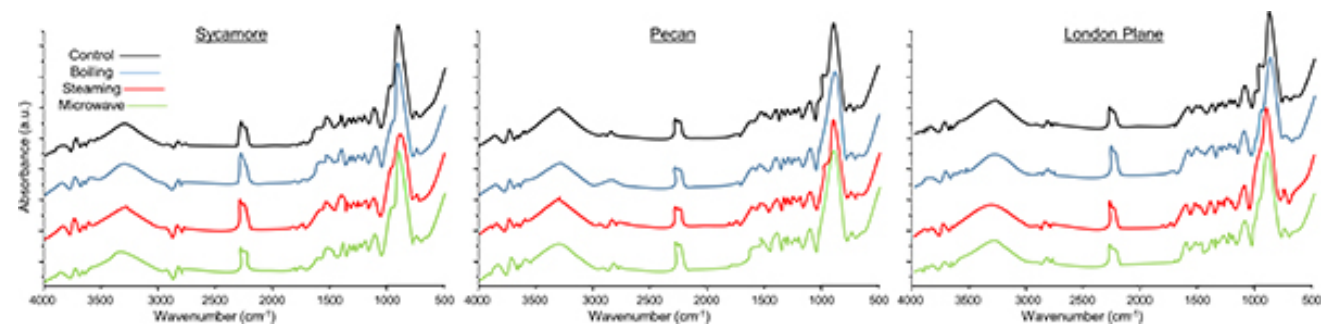

Figure 1: Infrared spectra for the control group and treated hardwoods.

\section{Roughness}

All the treatments yielded smaller roughness parameters when compared to the pristine samples, which indicates effective surface inactivation mechanisms (Figure 2). On the other hand, the roughness did not vary in a comparison between treated woods, nor between wood species. 


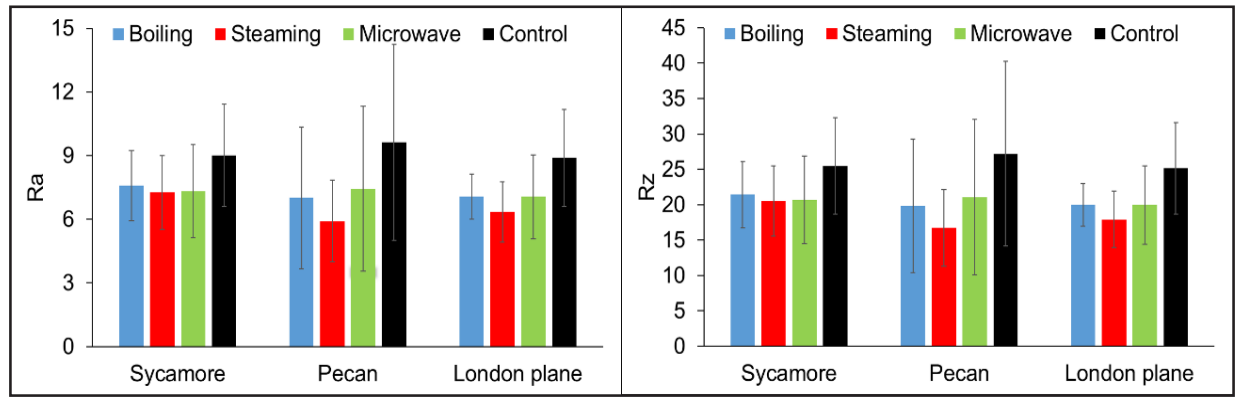

Figure 2: Surface roughness for the control group and treated hardwoods. Where Ra is roughness average and $\mathrm{Rz}$ is mean peak to-valley height.

However, the steamed pecan wood was an exception and presented significant decreases in roughness parameters compared to the other treated pecan woods $(\mathrm{F}=7,65$ and $\mathrm{p}<0,01$ for $\mathrm{Ra}$ and $\mathrm{F}=7,55$ and $\mathrm{p}<0,01$ for $\mathrm{Rz})$. Among the studied wood species, the pecan presents the lowest fibre length, which indirectly indicates both low cellulose content and high lignin content (Aguayo et al. 2010, Kiaei et al. 2014). Based on that, this finding is probably related to a not fully understood effect of steam in the lignin from pecan wood. Some previous authors reported partly solubilisation, plasticization and sometimes condensation of certain chemical groups from lignin due to hydrothermal treatments (Kim et al. 2014, Hughes et al. 2015). According to Hughes et al. (2015), hydrothermal treatments can also induce a lignin fragmentation, producing a hornification mechanism. In this sense, results obtained by analytical methods applied to analyse wood polysaccharides may clarify this point (perhaps using gas chromatography mass spectrometry).

\section{Wettability}

ANOVA results showed that the surface wettability varied according to both treatment $(F=2896 ; p<0,01)$ and specie $(\mathrm{F}=798 ; \mathrm{p}<0,01)$. The last factor is related to the anatomical features of the selected woods and, in this sense, the sycamore has both highest fibre diameter and fibre thickness than the other wood fibres (Delucis et al. 2014a). In light of these anatomical features, the highest wettability for sycamore may be attributed to a capillary effect related to its large fibres or a high amount of amorphous components onto its thick cell wall. Representative wettability results were shown in Figure 3, which were selected based on the contact angle averages and indicate that all the contact angle kinetics are similarly shaped.

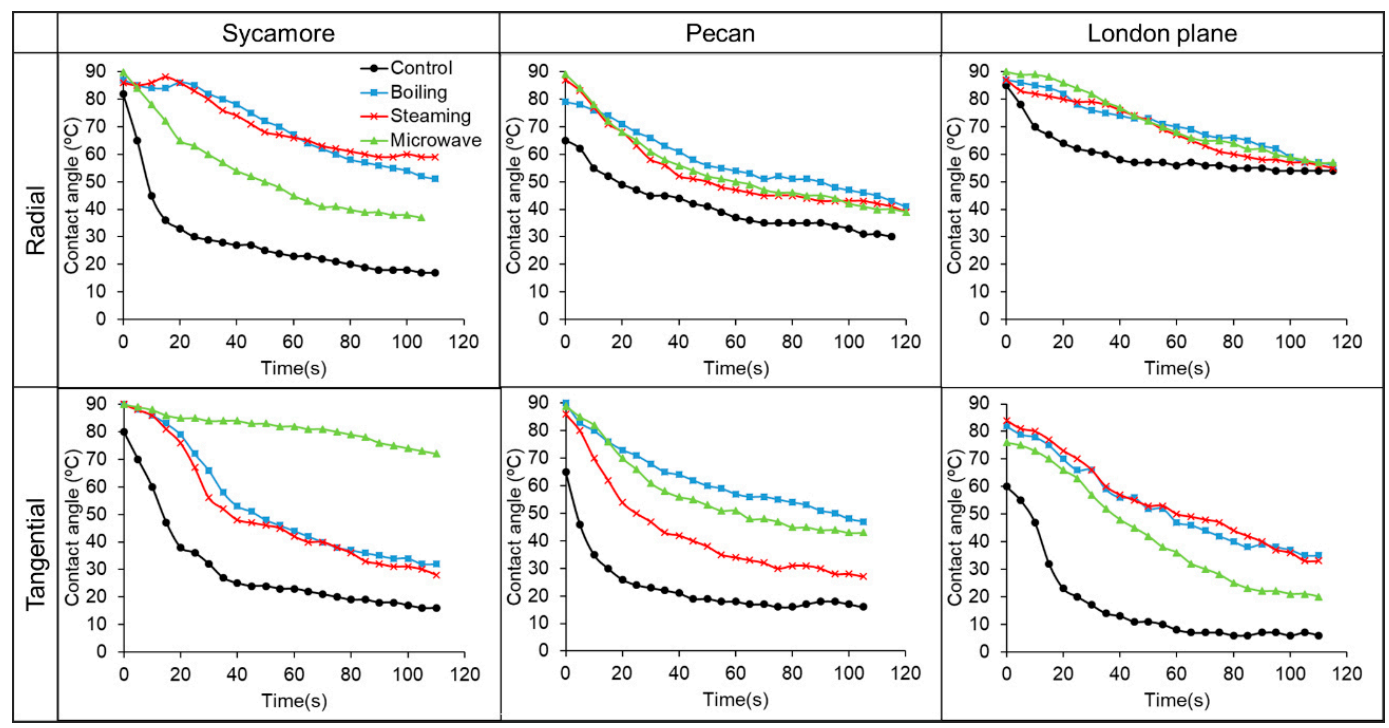

Figure 3: Representative contact angle kinetics for the control group and treated hardwoods. 
Besides of that, regarding the wood plane (radial and tangential), there was a smaller wettability on the radial plane if compared to the tangential plane $(\mathrm{F}=1371 ; \mathrm{p}<0,05)$, what can also be explained by anatomical elements, especially rays and vessels, which are exposed on the radial plane. This was previously reported for thermally (Cademartori et al. 2013) and hydrothermally (Herrera et al. 2015) treated woods.

Although presented the highest wettability in the pristine condition, the hydrothermally treated sycamore woods presented the highest increases in contact angle, which indicates a higher susceptibility to the hydrothermal treatments. It may be related to its chemical composition, including thermal degradation of amorphous segments in both hemicellulose and cellulose (Metsä-Kortelainen and Viitanen 2012), plasticization and condensation of some chemical groups from lignin (Kim et al. 2014) and migration of extractives onto the wood surface (Frybort et al. 2014).

Among the hydrothermal treatments, boiling induced the most significant effect on the contact angle, followed by steaming and microwave, except for the sycamore wood on the tangential plane. Among the wood species, the sycamore wood was mostly susceptible to the steaming treatment, which also may be related to its anatomical characteristics, since its robust wood fibres probably were slightly most resistant against the internal pressure developed in the cell wall under vapour action.

\section{Colour}

The $L^{*}$ levels decreased for all species after the treatments, which represent the darkening of their colours (Figure 4). The higher darkening was provided by microwave radiation on pecan and sycamore woods with $L^{*}$ decreases of $7,47 \%$ and $7,42 \%$, respectively. The darkening on wood surface attributed to heat action is due to changes on double bonds from extractives (Tolvaj et al. 2012). Regarding the microwave radiation, significant colour changes on wood surface indicates a successfully performed treatment, since wood samples were previously waterlogged and, for this reason, the wood-steam interactions occur from inside to outside the wood (Peres et al. 2016). According to Mattos et al. (2015), darkened colour patterns are related to high value wood products.

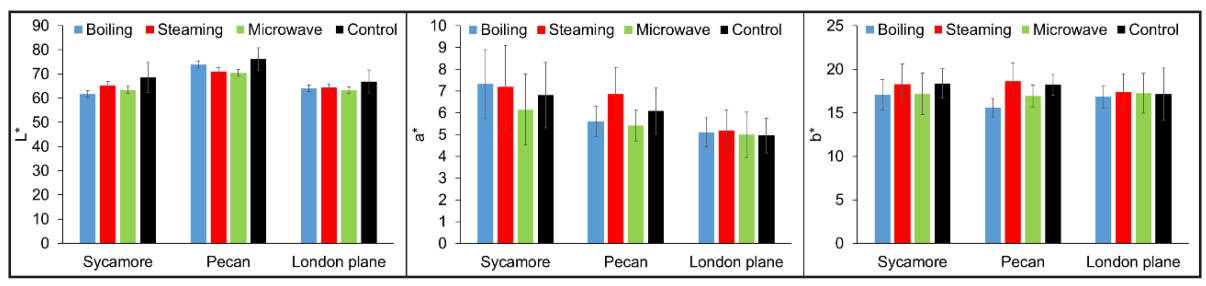

Figure 4: Colour parameters for the control group and treated hardwoods.

Regarding both the yellow and red pigments (indicated by $\mathrm{a}^{*}$ and $\mathrm{b}^{*}$ levels, respectively), there are loss and sometimes gains in the averages, which may be attributed to the different chemical composition of the three studied hardwoods. According to Delucis et al. (2014b), the a* levels present a close relationship with phenolic compounds. On the other hand, Romagnoli et al. (2013) reported an elucidative study with Tabebuia serratifolia wood and, according to these authors, the $b^{*}$ levels were attributed to the presence of particular wood extractives, especially naphthoquinones, such as lapachol and dehydro- $\alpha$-lapachone.

\section{Mechanical properties}

In general, the hydrothermal treatments yielded both decreased stiffness and strength (Figure 5). Among the treated ones, there were no significant differences based on ANOVA results. The sycamore wood presents the naturally highest mechanical properties, which can be attributed to its long and wide wood fibres. These changes in mechanical properties are probably related to degradation mechanisms in certain amorphous segments from wood polysaccharides, as below discussed. According to Cademartori et al. (2013), for instance, the hemicelluloses are degraded by the loss of acetyl groups that become acetic acid. This degradation also includes depolymerisation and hornification processes (Hughes et al. 2015). As possible effects from the wood 
heating, some authors also reported cracks in wood vessels (Huang et al. 2012) and drying defects (Boonstra et al. 2006).

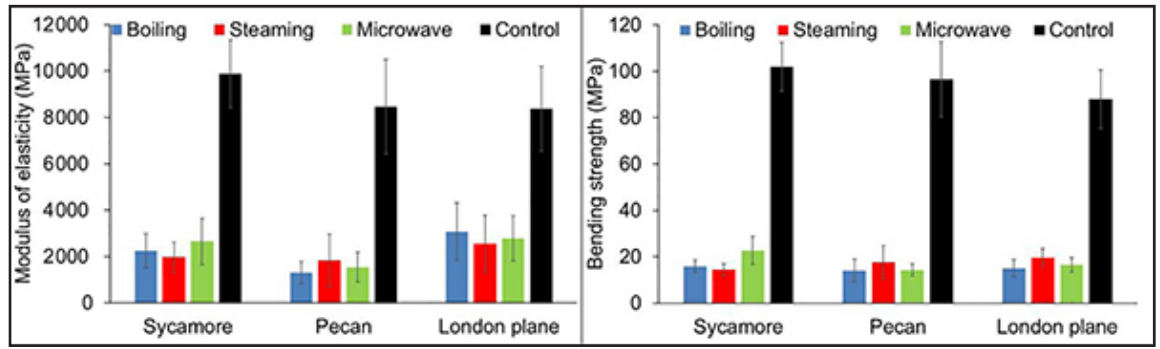

Figure 5: Bending properties for the control group and treated hardwoods.

Besides of the mechanical properties, the hydrothermal treatments yielded increased deflectibility, as shown in Figure 6. This Figure displays representative load vs. deflection curves selected based on those previously presented averages for mechanical properties. The pecan wood presented the highest deflection at break, which can be attributed to its highest lignin content, as below discussed. Previous authors obtained similar mechanical behaviours for hydrothermally treated woods and attributed that to conformational arrangements of some biopolymers from wood, probably associated with plasticization and condensation mechanisms in lignin (Kim et al. 2014). Some authors also reported that solid wood products with high ability of absorb energy under mechanical loads may be applied for several structural applications (Arnold 2010, Widmann et al. 2012).
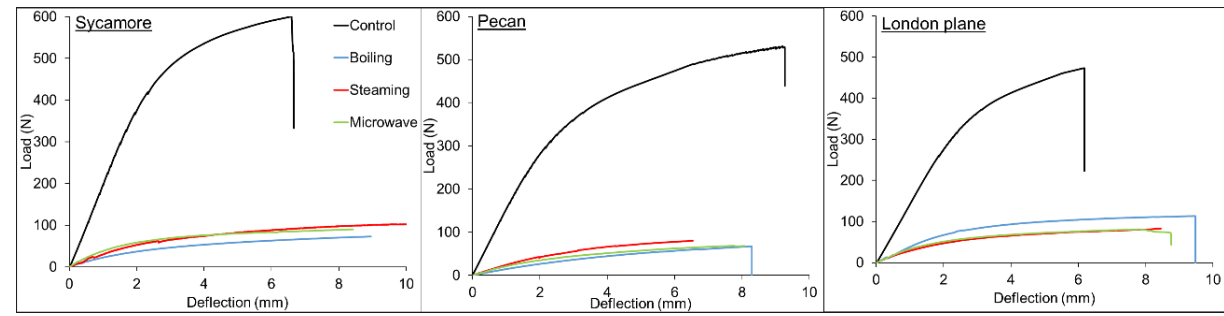

Figure 6: Representative load versus deflection curves for the control group and treated hardwoods.

\section{CONCLUSIONS}

In this study, surface inactivation mechanisms and changes in mechanical features were induced by three different hydrothermal treatments in three different hardwoods. These modifications were successfully portrayed using results from infrared spectroscopy, roughness, wettability, colour and bending tests. In general, the hydrothermal treatments caused a certain surface inactivation, marked by decreased surface roughness, increased hydrophobic character and darkened colour patterns. Also, decreased stiffness and strength and increased deflectibility were obtained. These mechanisms were attributed to degradation in fine segments from amorphous polysaccharides, leaching of some organic extractives and fragmentation of lignin, as indirectly indicated by infrared spectra. The boiling treatment caused the highest decrease in the contact angle. On the other hand, the steaming treatment was the most effective in reduce the surface roughness for the pecan wood. The sycamore wood was the most affected wood by the hydrothermal treatments, as indicated by contact angle measurements. The pecan wood presented the highest deflection at break, which can be attributed to its highest lignin content, which can be of interest to conform curved parts. 


\section{REFERENCES}

Aguayo, M.G.; Quintupill, L.; Castillo, R.; Baeza, J.; Freer, J.; Mendonça, R.T. 2010. Determination of differences in anatomical and chemical characteristics of tension and opposite wood of 8-year old Eucalyptus globulus. Maderas-Cienc Tecnol 12(3): 241-251. https://doi.org/10.4067/S0718-221X2010000300008

ASTM. 2017. Standard practice for sampling forest trees for determination of clear wood properties. ASTM D5536. 2017. ASTM: West Conshohocken, USA. https://doi.org/10.1520/D5536-17

ASTM. 2014. Standard test methods for small clear specimens of timber. ASTM D143. 2014. ASTM: West Conshohocken, USA. https://doi.org/10.1520/D0143-14

Arnold, M. 2010. Effect of moisture on the bending properties of thermally modified beech and spruce. $J$ Mater Sci 45(3): 669-680. https://doi.org/10.1007/s10853-009-3984-8

Aydin, I.; Demirkir, C. 2010. Activation of spruce wood surfaces by plasma treatment after long terms of natural surface inactivation. Plasma Chem Plasma $P$ 30(5): 697-706. https://doi.org/10.1007/s11090-010-9244-5

Biziks, V.; Acker, J.V.; Militz, H.; Grinins, J.; Bulcke, J.V. 2019. Density and density profile changes in birch and spruce caused by thermos-hydro treatment measured by X-ray computed tomography. Wood Sci Technol 53(2): 491-504. https://doi.org/10.1007/s00226-018-1070-6

Boonstra, M.J.; Rijsdijk, J.F.; Sander, C.; Kegel, E.; Tjeerdsma, B.F.; Militz, M.; Van Acker, J.; Stevens, M. 2006. Microstructural and physical aspects of heat treated wood. Part 1. Softwoods. Maderas-Cienc Tecnol 8(3): 193-208. http://dx.doi.org/10.4067/S0718-221X2006000300006

Cademartori, P.H.G.; dos Santos, P.S.B.; Serrano, L.; Labidi, J.; Gatto, D.A. 2013. Effect of thermal treatment on physicochemical properties of Gympie messmate wood. Ind Crop Prod 45: 360-366. https://doi.org/10.1016/j.indcrop.2012.12.048

Delucis, R.A.; Stangerlin, D.M.; Beltrame, R.; Gatto, D.A. 2014a. Métodos de delimitação dos lenhos juvenil e adulto de três folhosas e propriedades biométricas de suas fibras. Rev Arvore 38(5): 943-950. http://dx.doi.org/10.1590/S0100-67622014000500019

Delucis, R.A.; Taborda, V.C.; Correa, L.W.; Vega, R.A.; Gatto, D.A. 2014b. Avaliação da cor dos lenhos juvenil e adulto de cedro por meio do método CIEL*A*B*. Tecnologia em Metalurgia, Materiais e Mineração 11(3): 251-259. http://dx.doi.org/10.4322/tmm.2014.037

Frybort, S.; Obersriebnig, M.; Müller, U.; Gindl-Altmutter, W.; Konnerth, J. 2014. Variability in surface polarity of wood by means of afm adhesion force mapping. Colloid Surface A 457: 82-87. https://doi.org/10.1016/j.colsurfa.2014.05.055

Gatto, D.A.; Haselein, C.R.; Santini, E.J.; Marchiori, J.N.C.; Durlo, M.A.; Calegari, L.; Stangerlin, D.M. 2008. Características tecnológicas das madeiras de Luehea divaricata, Carya illinoinensis e Platanus $x$ acerifolia quando submetidas ao vergamento. Cienc Florest 18(1): 121-131. http://dx.doi.org/10.5902/19805098516

Gérardin, P.; Petrič, M.; Petrissans, M.; Lambert, J.; Ehrhrardt, J.J. 2007. Evolution of wood surface free energy after heat treatment. Polym Degrad Stabil 92(4): 653-657. https://doi.org/10.1016/j.polymdegradstab.2007.01.016

Gündüz, G.; Korkut, S.; Korkut, D.S. 2008. The effects of heat treatment on physical and technological properties and surface roughness of camiyani black pine (Pinus nigra Arn. Subsp. Pallasiana Var. Pallasiana) wood. Bioresource Technol 99(7): 2275-2280. http://dx.doi.org/10.1016/j.biortech.2007.05.015

Herrera, R.; Xabier, E.; Llano-Pontes, R.; Labidi, J. 2015. Chemical analysis of industrial-scale hydrothermal wood degraded by wood-rotting basidiomycetes and its action mechanisms. Polym Degrad Stabil 117: 37-45. http://dx.doi.org/10.1016/j.polymdegradstab.2015.03.013 
Huang, X.; Kocaefe, D.; Kocaefe, Y.; Boluk, Y.; Pichette, A. 2012. Changes in wettability of heat-treated wood due to artificial weathering. Wood Sci Technol 46: 1215-1237. https://doi.org/10.1007/s00226-012-0479-6

Hughes, M.; Hill, C.; Pfriem, A. 2015. The toughness of hygrothermally modified wood - a review. Holzforschung 69(7): 1-12. https://doi.org/10.1515/Hf-2014-0184

JIS. 2001. Surface roughness. JIS B0621. JIS: Tokyo, Japan.

Kim, J.Y.; Hwang, H.; Oh, S.; Kim, Y.S.; Kim, U.J.; Choi, J.W. 2014. Investigation of structural modification and thermal characteristics of lignin after heat treatment. Int J Biol Macromol 66: 57-65. https://doi.org/10.1016/j.ijbiomac.2014.02.013

Kiaei, M.; Kord, B.; Vaysi, R. 2014. Influence of residual lignin content on physical and mechanical properties of kraft pulp/PP composites. Maderas-Cienc Tecnol 16(4): 495- 503. https://doi.org/10.4067/S0718-221X2014005000040

Mattos, B.D.; de Cademartori, P.H.G.; Magalhães, W.L.E.; Lazzarotto. M.; Gatto, D.A. 2015. Thermal tools in the evaluation of decayed and weathered wood polymer composites prepared by in situ polymerization. J Therm Anal Calorim 121(3): 1263-1271. https://doi.org/10.1007/s10973-015-4647-4

Metsä-Kortelainen, S.; Viitanen, H. 2012. Wettability of sapwood and heartwood of thermally modified Norway spruce and scots pine. Eur J Wood Wood Prod 70: 135-139. https://doi.org/10.1007/s00107-011-05235

Ozarska, B.; Daian, G. 2010. Assessment of microwave bending capabilities for Australian wood species. Forest Prod J 60(1): 64-68. https://doi.org/10.13073/0015-7473-60.1.64

Pandey, K.A. 1999. A study of chemical structure of soft and hardwood and wood polymers by FTIR spectroscopy. J Appl Polym Sci 71(12): 1969-1975. https://doi.org/10.1002/(SICI)1097-4628(19990321)71:1 2<1969::AID-APP6>3.0.CO;2-D

Peres, M.L.; Delucis, R.A.; Gatto, D.A.; Beltrame, R. 2016. Mechanical behavior of wood species softened by microwave heating prior to bending. Eur J Wood Wood Prod 74(2): 143-149. https://doi.org/10.1007/s00107-015-0978-x

Piao, C.; Winandy, J.E.; Shupe, T.F. 2010. From hydrophilicity to hydrophobicity: A critical review: Part I. Wettability and surface behavior. Wood Fiber Sci 42(4): 490-510. https://wfs.swst.org/index.php/wfs/article/view/2144

Placet, V.; Passard, J.; Perré, P. 2008. Viscoelastic properties of wood across the grain measured under water-saturated conditions up to $135{ }^{\circ} \mathrm{C}$ : evidence of thermal degradation. J Mater Sci 43(9): 3210-3217. https://doi.org/10.1007/s10853-008-2546-9

Romagnoli, M.; Segoloni, E.; Luna, M.; Margaritelli, A.; Gatti, M.; Santamaria, U.; Vinciguerra, V. 2013. Wood colour in lapacho (Tabebuia serratifolia): Chemical composition and industrial implications. Wood Sci Technol 47(4): 701-716. https://doi.org/10.1007/S00226-013-0534-Y

Tolvaj, L.; Papp, G.; Varga, D.; Lang, E. 2012. Effect of steaming on the colour change of softwoods. Bioresources 7(3): 2799-2808. https://bioresources.cnr.ncsu.edu/resources/effect-of-steaming-on-the-colourchange-of-softwoods/

Widmann, R.; Fernandez-Cabo, J.L.; Steiger, R. 2012. Mechanical properties of thermally modified beech timber for structural purposes. Eur J Wood Wood Prod 70: 775-784. https://doi.org/10.1007/s00107-012-0615-x 